\title{
Research on the possibilities of building in Natura 2000 sites in Poland on the example of Warmia and Mazury Province
}

Jolanta Harasymiuk $^{1 *}$, Elżbieta Hanna Szafranko ${ }^{2}$, Joanna Agnieszka

Pawłowicz ${ }^{3}$

\author{
University of Warmia and Mazury in Olsztyn
}

${ }^{1,2,3}$ Faculty of Geodesy, Geospatial and Civil Engineering, Heweliusza Street 4, Olsztyn,

Poland PL 10-724

${ }^{1}$ jolanta.harasymiuk@uwm.edu.pl, ${ }^{2}$ elasz@uwm.edu.pl, ${ }^{3}$ jopaw@uwm.edu.pl

Keywords: Natura 2000 sites, Poland, building investment

\begin{abstract}
Natura 2000 sites are the largest network of protected nature reserves in Europe. These areas have a significant influence on planning investments in the member states of the EU, also in Poland since completion of building investments within their geographic limits, which could have a negative impact on the integrity of these areas is forbidden. Natura 2000 sites in Poland are coordinated by Regional Directors of Environment Protection, who have the right among other things to issue opinions about the necessity of carrying out an assessment of building investments in Natura 2000 sites. Such an opinion is issued during the planning stage of a building investment and it is crucial from the point of view of the aim of an assessment, which is the elimination of a significant negative impact in Natura 2000 sites. The aim of this study is an analysis of the opinions issued by the regional director of environment protection in Olsztyn in the years 2012-2015 with regard to required building investment. The paper also analyses Natura 2000 sites in Warmia and Mazury Province with regards to their attractiveness for investors as a place for building investment.
\end{abstract}

\section{Introduction}

Natura 2000 as a form of environment protection was introduced in Poland in 2004 as a consequence of joining the European Union. It consists of 3 distinct systems of protected sites, delineated according to the EU regulations [1]:

- sites of birds refuge,

- special sites of habitat protection, delineated with the aim of natural habitats as well as habitats of plant and animal species but without birds,

- Sites of Community Importance (SCI).

An site of a special birds' protection is an site delineated with the aim of protection of wild population of birds, of one or many species, according to the Directive 2009/147/EC ("Birds" Directive [2].

Special sites of habitat protection are sites delineated with the aim of constant protection of natural habitats and endangered species of plants and animals but without birds according to the Directive 92/43/EEC ("Habitats" Directive) [3].

Natura 2000 sites are given individual names, and they are provided additionally with alphanumeric codes. Birds reserves have the codes commencing with the letters PLB, and habitat reserves with - PLH.

Processes of creating Natura 2000 areas in Poland are complex and they carry out differently in the case of areas of special protection of birds and of special areas of habitat protection. These first include the domestic stage (delineation of a concrete area on the force of a decree of the Environment Minister) and the stage at the level of the European Union (acceptance of an area by the European Commission). The latter assume passing of a list of the proposed areas, which are at the same time Sites of Community Importance of the Environment Minister to the European 
Commission. After handing the list, these areas are ascribed to individual biogeographic regions ${ }^{1}$. The key element of the procedure is a Biogeographic Seminar, during which the completeness of the network for each species and habitat subjects to protection is evaluated. Then the European Commission ratifies in the form of a formal decision these areas as Site of Community Importance SCI. Since then they get the status of Natura 2000 areas, and member states are obliged to delineate these reserves as special areas of protection within 6 years after the decision of the European Commission.

According to Birds and Habitats Directives [2,3], Natura 2000 Sites are not conceived of as nature reserves where investors' activities are forbidden [4]. Every building investment, which can significantly influence the protection goals of a given Natura 2000 site, and is not directly related to its protection, requires, however, an assessment of its impact on this site. The regulations do not determine a list of undertakings which require an assessment. This situation may be a surprise for the investors who do not know the environmental requirements for a building investment and may result in the delay of the building process.

As an assessment of the impact of a building investment on a Natura 2000 site is to be understood as an assessment of the impact of this investment on the environment. It is limited to an analysis of its impact on a Natura 2000 site. An important element of an assessment (in the literature described as a habitat assessment) is the opinion issued by the appropriate Regional Director of Environment Protection $^{2}$ (RDEP) for the locality of a planned investment [5]. Opinions are necessary to prevent a situation, in which an investment with a significantly negative impact on a Natura 2000 site will not be subjected to an assessment and an environmental report on it will not be made, which as the only one that has the chance of a thorough analysis or the probable impact of an investment on the integrity of a Natura 2000 site. On the other hand, an opinion of a RDEP concluding a lack of the need for an assessment eliminates the further procedure for investments with a low impact on valuable natural sites. The aim of this study is an analysis of the decisions taken in the Regional Office of Environment Protection in Olsztyn in the years of 2012 - 2015 with the view of the kinds of building investments, subject to this procedure. The paper also analyses the Natura 2000 sites in Warmia and Mazury Province with regard to the attractiveness of the investment.

\section{Methods}

The research began with an overview of the literature, which included: the literature on the subject as well as the regulations pertaining to the assessment of the impact of building investments in Natura 2000 site. Later the proper research was done, in the framework of which an analysis of documents of the administrative procedures conducted in the years of 2012-2015 by the Regional Office of Environment Protection in Olsztyn. A structured inquiry with three experts dealing with assessing an impact in Natura 2000 sites was also made. From the wide range of statistical methods used, descriptive statistical method was applied. It was used to describe building investments subject to administrative procedures from the viewpoint of their number and category as well as determining the share of "natural" sites - sites of the planned investment activities in the total number of Natura 2000 sites in the Province of Warmia and Mazury.

\footnotetext{
${ }^{1}$ In the case of Poland 9 executory decisions of the Commission on the acceptance of the up-to-date lists of the Sites of Community Importance.

${ }^{2}$ Regional Director of Environment Protection is a governmental body, appropriate locally for the area of a province. After the coming in force of the Parliamentary Act (2008), on the regional directors of environment protection (there are 16 of them, one in each province) were shifted all the competences foreseen so far for the clerks managing Natura 2000 sites (heads of provinces, directors of a marine office).
} 


\section{Results of research}

The province of Warmia and Mazury is the fourth largest in Poland with an sites of over 24 thousands sq $\mathrm{km}$. the natural attraction of the province (one of the purest and wildest of Poland) are the reasons for the interest in the terrain of Warmia and Mazury by private investors in the first place. In the province there are, wholly or partially, 16 sites of bird reseves (with the total sites of 575,809 ha) and 43 Sites of Community Importance (with the total sites of 258,190 ha).

The site of bird reserves, which in the period analysed was chosen most frequently by investors as the place of building investments was the Pisz Forest (code PLB280008)[5] (rys.1).

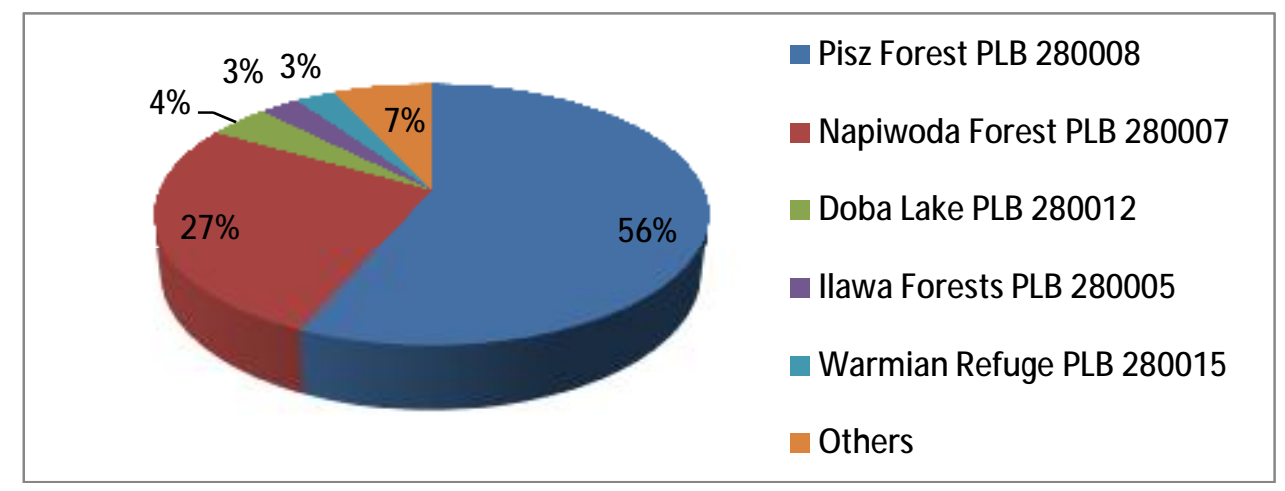

Fig. 1. The preferences of investors concerning the choice of Natura 2000 sites in the Warmia and Mazury Province in Poland as location of building investments in the years 2012-2015

This site is the seventh largest in the framework of Natura 2000 in Poland. It constitutes one of the most important habitat for birds of prey and owls nationwide. Five rare species of birds nest here, which are entered in the Polish Red Book of animals, whereas for the sea eagle it is the largest, for the black kite, the lesser spotted eagle the osprey - one of the main breeding grounds in the country. Maintenance of the habitats of the protected species of birds in the Pisz Forest is boggy marshlands and meadows as well as extensive animal husbandry run on the non-forest sites.

The Site of Community Importance, which constituted a potential site for planned investments was in the analysed period the Mazurian Tortoise Habitat Baranowo (code PLH280055) [6]. The reserve is of a special significance for the strong population of European pond turtle.

The research, conducted by the Author, included all of the opinions of the Regional Director of Environment Protection in Olsztyn confirming the necessity or lack of the necessity of making an assessment of the impact on the Natura 2000 sites of building investments issued in the years of 2012-2015. The quantitative analysis of these opinions including the kind of building investments is presented in Table 1.

The results of the research show that there was a drop in the number of the opinions issued which confirmed the need for a habitat assessment as well as those which did not state such an obligation. In both cases it was due to a lesser number of applications submitted by the investors.

The opinions issued by the Regional Director of Environment Protection pertain to undertakings of a various range (building new structures, repairs of existing building items), of a different kind: cubature buildings (SFRs, individual recreational buildings, stables, farmyard buildings), civil engineering infrastructure (roads culverts, fish ponds, recreational piers), linear infrastructure 
Table 1. Decisions of the Regional Director of Environment Protection in Olsztyn considering the grounds for making an assessment of the impact on an Natura 2000 sites of building investments in the years of 2012-2015.

\begin{tabular}{|l|c|c|c|c|c|}
\hline $\begin{array}{l}\text { Decisions of the Regional Director of Environment } \\
\text { Protection and kinds of building investments in the } \\
\text { analysed period }\end{array}$ & 2012 & 2013 & 2014 & 2015 & Total \\
\hline $\begin{array}{l}\text { I.Confirming the obligation of a habitat assessment } \\
\text { for building investments which involve: }\end{array}$ & 30 & 22 & 16 & 11 & 79 \\
\hline a. building single - family houses, & 14 & 6 & 8 & 6 & 34 \\
b. building farmyard facilities, & 6 & 7 & 3 & 1 & 17 \\
c. building tourist and recreational facilities, & 2 & 1 & 1 & 1 & 5 \\
d. building linear infrastucture, & 5 & 1 & - & - & 6 \\
e. building engineering facilities. & 3 & 7 & 4 & 3 & 17 \\
\hline II. Not confirming the obligation of a habitat & 75 & 38 & 26 & 57 & 196 \\
assessment for building investments consisting in: & & & & & \\
\hline a. building single - family houses, & 36 & 19 & 17 & 31 & 103 \\
b. building farmyard facilities, & 3 & 5 & 2 & 3 & 13 \\
c. building service facilities, & 2 & - & - & 1 & 3 \\
d. building tourist and recreational facilities, & 7 & 3 & 1 & 8 & 19 \\
e. building line investments, & 12 & 3 & - & 7 & 22 \\
f. building engineering facilities, & 15 & 7 & 6 & 7 & 35 \\
g. building animal refuge. & - & 1 & - & - & 1 \\
\hline Total I and II & 105 & 60 & 42 & 68 & 275 \\
\hline
\end{tabular}

(commune roads, hard surface pedestrian paths, water networks, sewage systems and electrical grids, guided borings under water courses), of a different scale of impact (individual items or their complexes) and the form of property (private and public investments).

No building investment which was subject to the opinion of the Regional Director of Environment Protection was not related to or indispensable for the management of a Natura 2000 sites $^{3}$.

The majority of the planned building investments in the two categories (i.e. requiring and not requiring a habitat assessment) consisted of SFRs. This situation might lie in the fact, that the investors got used with the legal regime binding during planning of this kind of building development in valuable natural sites and they stopped being afraid of submitting their investments to the procedure of an assessment. In response to the market demand the offers of design offices include now also typical projects dedicated to particular conditions, what enables the investors to meet the requirements for SFRs easier in the sensitive natural sites.

The obligation of a habitat assessment for this kind of building development was introduced as a result of the intention of building detached SFRs in small-sites complexes, non-built-up lots within the borders of Natura 2000 sites, for which Standard Data Forms ${ }^{4}$ mentioned the settlement pressure as a threat.

In the category of undertakings which are not subject to an assessment of impact on Natura 2000 sites, a slight upward trend can be observed with regard to the investments of farmyard buildings and constant trend in touristic accommodation. In the first case it results from the fact that

\footnotetext{
${ }^{3}$ In this case a building investment is not subject to an assessment of impact on Natura 2000 areas by law (unless it may have negative impact on adjacent areas).

${ }^{4}$ Standardised in the entire EU descriptive document including detailed information on Natura 2000 sites .
} 
a considerable part of the Natura 2000 sites includes not only forest and lakes but also agricultural land and meadows. Polish farmers form Natura 2000 sites could receive financial support from the EU to compensate disadvantageous conditions of operation, what could be a impulse for undertaking such investments. In the second case Natura 2000 sites with their high natural attractiveness started to be treated as an eco-product by the investors and a chance for revitalising terrains of already non-existant touristic infrastructure or it existed but of a low standard.

In the period analysed there was a decrease in all the categories of investments which required a habitat assessment. It can be a result of the fact that clerks after a few years of preparing assessments of impact on Natura 2000 sites started to conduct with more confidence and their doubts were not interpreted disadvantageously for an investor.

\section{Conclusion}

Numerous investors in Poland still perceive Natura 2000 sites as an obstacle in planning building investments. But completion of a building investment on the sites partially or wholly included to the European ecological network is not out of question. $71.3 \%$ opinions issued by the Regional Director of Environment Protection in Olsztyn in the years of 2012-2015 did not state a negative impact of the planned investments on the protected species of Natura 2000 sites nor on the integrity of those sites.

The opinions issued were treated in which the priority was given to the biology of the protected species in a given Natura 2000 sites. It resulted in the fact, that identical technically building investments might do or not a damage to the protected element of the sites. There is a need for preparing objective citeria of an assessment for the significance of an impact of the planned investment on the sensitive natural sites, in order they would be more clear for the investors and community.

\section{References}

[1] S. Lai, C. Zoppi: The Influence of Natura 2000 Sites on Land-Taking Processes at the Regional Level: An Empirical Analysis Concerning Sardinia (Italy), Sustainability 9, 259 (2017), p.1-26.

[2] Directive 2009/147/EC of The European Parliament and of The Council of 30 November 2009 on the conservation of wild birds (OJ L 20.7, 26.1.2010).

[3] Council Directive 92/43/EEC of 21 May 1992 on the conservation of natural habitats and of wild fauna and flora (OJ L 206/7, 22.7.92).

[4] F. Leone, C. Zoppi: Conservation Measures and Loss of Ecosystem Services: A Study Concerning the Sardinian Natura 2000 Network, Sustainability 8, 1061 (2016), p.1-15.

[5] J. Harasymiuk: Analysis of selected environmental procedures for construction investment, Ecological Engineering Vol. 18, Iss. 4 (2017), p. 79-88 (in Polish).

[6] J. Harasymiuk: The specifics of the methodology of conducting an assessment of the impact of building investment in the sites of Natura 2000 in light of own research, Acta Sci. Pol. Architectura 16 (1) (2017), p. 47-54.

[7] Information on http://natura2000.eea.europa.eu/Natura2000/SDF.aspx?site=PLB280008.

[8] Information on http://natura2000.eea.europa.eu/Natura2000/SDF.aspx?site=PLH280055. 